\title{
Złote czasy radia. Edukacyjne i wychowawcze funkcje radiowych audycji umuzykalniających
}

\section{KEY WORDS}

radio broadcast, music education, pre-school education, rhythmics, Polish Radio

\begin{abstract}
Forecka-Waśko Katarzyna, Złote czasy radia. Edukacyjne i wychowawcze funkcje radiowych audycji umuzykalniających [Golden Age of Radio. Educational and Didactic Aims of Music Radio Broadcasts]. Kultura - Społeczeństwo - Edukacja nr 2(10) 2016, Poznań 2016, pp. 215-230, Adam Mickiewicz University Press. ISSN 2300-0422. DOI 10.14746/kse.2016.10.17.

The article attempts to present the specificity of radio music broadcasts as a form of didactic method used while teaching children about music. The Polish Radio music broadcasts created by Maria Wieman from 1946 to 1976 were used as a research material.

The author shows the historical background in which educational radio programmes were made in Poland. The state of kindergarten education after the war and the methodology of music education is also adressed. The paper attempts to present the reconstruction of the formation of music broadcasts for children based on the literature dedicated to the subject, recordings of the broadcasts, and radio documents. The author also wanted to present the profile of Maria Wieman, the brodcast creator. Her methodological and didactic achievements played a key role in forming the modern way of thinking about music education in kindergarten.
\end{abstract}

\section{Trudne początki}

Umuzykalnienie stanowi jeden $\mathrm{z}$ obszarów wychowania dziecka uwzględniany przez wszystkie programy wychowania w przedszkolu po II wojnie światowej. W latach powojennych powoli zaczęła kształtować się polska pluralistyczna koncepcja wychowania muzycznego, zakładająca różnorodność kontaktów dziecka z muzyką i podkreślająca równocześnie wychowawczy charakter muzycznego oddziaływania. W okresie przedwojennym audycje dla dzieci kierowane były jedynie do szkół podstawowych oraz liceów, dopiero po 1945 roku radio rozszerzyło swoją działalność edukacyjną z myślą o najmłodszych słuchaczach (zob. 
Gawrecki, 1970: 7). Audycje radiowe dla przedszkoli po raz pierwszy pojawiły się na antenie Polskiego Radia w roku szkolnym 1948/1949 (Wieman, 1959). W sytuacji deficytów kadrowych, braku pomocy dydaktycznych w placówkach przedszkolnych, a także przeznaczonej dla dzieci literatury muzycznej Polskie Radio przyjęło funkcję swoistego rodzaju edukatora.

$\mathrm{W}$ okresie powojennym jednym $\mathrm{z}$ najważniejszych zadań oświatowych było rozwijanie sieci przedszkoli celem zapewnienia najmłodszym dzieciom warunków prawidłowego funkcjonowania i należytej opieki zdrowotnej ${ }^{1}$. Rosła bowiem wówczas świadomość funkcji przedszkola, które zostało uznane za pierwszy szczebel edukacji powszechnej, należało zatem objąć nią znaczącą liczbę dzieci². W ówczesnych warunkach dotkliwych braków lokalowych i kadrowych trudno było jednak mówić o wdrażaniu, poza podstawowym programem wychowania w przedszkolu, oddzielnie realizowanej edukacji muzycznej. Większość przedszkoli nie posiadała pomocy dydaktycznych do prowadzenia tego rodzaju zajęć, nie wspominając o możliwości zatrudnienia osób z wykształceniem muzycznym.

Mówiąc o braku pomocy dydaktycznych, należy zauważyć, że dotyczył on nie tylko instrumentów muzycznych, ale przede wszystkim podręczników, śpiewników i innych opracowań związanych z edukacją muzyczną dzieci. Takie opracowania wcześniej nie istniały. Ich powstawanie po II wojnie światowej było ściśle związane z kształtowaniem polskiej koncepcji wychowania muzycznego w oparciu o nowe systemy wychowania muzycznego E. Jaques-Dalcroze’a i C. Orffa oraz praktyczne i teoretyczne dokonania polskich pedagogów.

Maria Przychodzińska-Kaciczak opisuje sytuację wychowania muzycznego po 1948 roku w następujący sposób:

(...) $\mathrm{w}$ latach czterdziestych i pięćdziesiątych wychowanie muzyczne zajmowało $\mathrm{z}$ wielu różnych przyczyn, głównie programowych i kadrowych, marginesową rolę na tle treści i celów eksponowanych w programach. (Przychodzińska-Kaciczak, 1979: 129)

Zajęcia umuzykalniające znalazły jednak swoje miejsce już w Tymczasowym programie wychowania w przedszkolu $\mathrm{z}$ roku $1951^{3}$, a w kolejnych programach zakres form aktywności muzycznej dziecka i realizowanych treści wychowania muzycznego ulegał rozszerzeniu. Ten proces miał związek zarówno z rozwojem

\footnotetext{
${ }^{1}$ Dziennik Urzędowy Ministerstwa Oświaty 1948 Nr 6, Poz. 111 Instrukcja z dnia 29 maja 1948 (Nr II WP-2732/48) w sprawie organizacji wychowania przedszkolnego na rok 1948/49, s. 225-226.

${ }^{2},(\ldots)$ Celem wychowania w przedszkolu jest doprowadzenie do szkoły podstawowej dzieci prawidłowo rozwiniętych fizycznie, psychicznie i umysłowo, wychowanych w duchu kultury i pedagogiki socjalistycznej”, zob.: Ministerstwo Oświaty, Projekt Programu wychowania w Przedszkolu, Państwowe Zakłady Wydawnictw Szkolnych, Warszawa 1949.

${ }^{3}$ Ministerstwo Oświaty, Program Tymczasowy „Zajęcia w przedszkolu”, Państwowe Zakłady Wydawnictw Szkolnych, Warszawa 1950.
} 
teorii wychowania muzycznego w Polsce, jak i praktycznymi dokonaniami, na które składały się przede wszystkim kolejne publikacje $\mathrm{z}$ tej dziedziny oraz zaangażowanie muzyków w poprawę jakości kształcenia muzycznego. Znaczącą rolę odegrała $\mathrm{w}$ tym złożonym procesie wspomniana na wstępie edukacyjna misja Polskiego Radia, które od października 1948 roku emitowało audycje prezentujące zagadnienia związane $\mathrm{z}$ edukacją muzyczną $\mathrm{w}$ przedszkolu $\mathrm{w}$ oparciu o mało jeszcze wówczas rozpowszechnioną metodę rytmiki. Niewątpliwe znaczenie dla rozwoju metodyki wychowania muzycznego dziecka w wieku przedszkolnym miała działalność dydaktyczna i publicystyczna Marii Wieman, autorki wielu podręczników, śpiewników oraz audycji umuzykalniających dla przedszkoli, emitowanych przez Polskie Radio w latach 1948-1976. Wprawdzie audycje autorstwa Marii Wieman miały początkowo charakter tymczasowy, stały się jednak istotną formą wychowania muzycznego w przedszkolu, która przez prawie 30 lat wypełniała zadania związane z umuzykalnieniem dzieci.

Polskie Radio zaczęło realizować i wspierać wybrane zagadnienia związane z edukacją i wychowaniem zdalnym, wykorzystując możliwość dotarcia do zradiofonizowanych przedszkoli i tym samym wyrównywać szanse edukacyjne dzieci z obszarów wiejskich. Proces powszechnej radiofonizacji placówek oświaty rozpoczął się w roku 1947 i realizowany był konsekwentnie przez Społeczny Komitet Radiofonizacji Kraju ${ }^{4}$. Dzięki temu edukacyjna misja radia miała coraz większy zasięg, powstawały liczne audycje dla szkół (Kubin, 1957: 10) i placówek przedszkolnych. Początkowo dla przedszkoli nadawano audycje muzyczne i literackie, $\mathrm{z}$ czasem oferta została rozszerzona o audycje ortofoniczne. Ponadto dla dzieci $\mathrm{w}$ wieku przedszkolnym emitowane były audycje do samodzielnego słuchania w domu, zaś w czasie wakacji powstawały audycje dla dziecińców wiejskich (Hermelin, 1970: 31-36).

Utrzymanie i wzbogacanie oferty programowej dla dzieci najmłodszych świadczyło o rosnącym zainteresowaniu ich odbiorem. Cykl audycji umuzykalniających prowadzony był od roku 1948 aż do lat 80., czyli do rozkwitu telewizji i powstania programu dedykowanego dzieciom w wieku przedszkolnym „Domowe Przedszkole".

\section{W redakcyjnej kuchni: organizacja i planowanie audycji muzycznych}

Za całokształt prac nad emisją programów radiowych dla przedszkoli odpowiedzialna była Redakcja Audycji Przedszkolnych, będącą częścią Naczelnej Rady

\footnotetext{
${ }^{4}$ Zob.: Dziennik Urzędowy Ministerstwa Oświaty Nr 12, Okólnik Nr 28, z dnia 6 listopada 1948, w sprawie radiofonizacji szkół, Poz. 227, s. 539.
} 
Audycji Dziecięcych i Teatru dla Dzieci, której kierowniczką została Halina Hermelin (Hermelin, 1970: 8). Obok Redakcji Audycji Przedszkolnych skład Rady stanowiły następujące redakcje: Rada Audycji Muzycznych dla Dzieci, Redakcja Audycji Literackich dla Dzieci, Redakcja Audycji Przyrodniczo-Technicznych dla Dzieci oraz Redakcja Audycji „Błękitna Sztafeta” (Kubin, 1964: 24). Trzeba wyjaśnić, że wymienione wyżej redakcje zajmowały się audycjami przeznaczonymi dla szkól, zatem Rada Audycji Muzycznych dla Dzieci przygotowywała zajęcia umuzykalniające dla uczniów, natomiast Redakcja Audycji Przedszkolnych przygotowywała materiał zarówno do audycji muzycznych, jak i literackich tylko dla przedszkoli.

Redakcja Audycji Przedszkolnych w roku 1948 rozpoczęła prace nad dwoma cyklami audycji: literackich i umuzykalniających, które początkowo miały charakter eksperymentalny (Kubin, 1964). Już wówczas współpracowali z nią znani muzycy, stale obecna była tam Maria Wieman, która od samego początku była współpracownikiem redakcji i autorką wszystkich audycji umuzykalniających, a także Franciszka Leszczyńska ${ }^{5}$ - kompozytorka, autorka piosenek i ilustracji muzycznych wykorzystanych w audycjach (Hermelin, 1970: 7). W rolę spikera wcielał się Wiesław Machowski (Wieman, 1959), zaś redaktorem muzycznym audycji była Magdalena Młynarska. Pierwsze audycje umuzykalniające pojawiły się w Polskim Radiu po raz pierwszy już w roku szkolnym 1948/1949. Był to cykl o nazwie „Zabawy Rytmiczne” podporządkowany obowiązującym wówczas założeniom programowym oraz uwzględniający roczne plany zajęć opracowywane przez wychowawczynie, co było możliwe dzięki ich wcześniejszemu pozyskaniu i poddaniu analizie porównawczej (Hermelin, Korn, Radziwiłł, Wieman, 1956: 85).

Zespół redakcyjny wypracował później praktykę układania konspektów audycji z niemal półrocznym wyprzedzeniem, by już trzy miesiące przed emisją szczegółowy plan audycji ukazać się mógł w miesięczniku „Wychowanie w Przedszkolu" (Hermelin, Korn, Radziwiłł, Wieman, 1956: 85). Opis audycji w tym czasopiśmie uwzględniał streszczenie jej treści, szczegółowe opisy zabaw, informacje o niezbędnych rekwizytach, a także słowa i nuty piosenek. W innych periodykach ukazywały się już tylko informacje o temacie planowanej audycji, na przykład w miesięczniku „Radio i Świat”, natomiast programy audycji przeznaczonych do indywidualnego odsłuchu $\mathrm{w}$ domu można było znaleźć w czasopiśmie „Miś”. Opisana powyżej rozszerzona formuła publikacji konspektu audycji w „Wychowaniu w Przedszkolu" nie towarzyszyła audycjom radiowym od samego początku, lecz została wprowadzona w roku 1951 wskutek badań pilotażowych, które

\footnotetext{
${ }^{5}$ Franciszka Leszczyńska występowała w audycjach muzycznych dla dzieci pod pseudonimem Monika Czyńska. Zob. Wieman, 1959.
} 
wskazały na taką właśnie potrzebę. Publikacje te miały pomóc wychowawczyniom w przygotowaniu się do audycji oraz umożliwić powtarzanie ćwiczeń umuzykalniających po ich zakończeniu (Wieman, 1959). Dzisiaj stanowią nieocenione źródło informacji.

Planowanie audycji było procesem złożonym, na tym etapie Maria Wieman zbierała potrzebny materiał muzyczny i literacki w postaci piosenek, opracowań tańców, przykładów muzyki klasycznej oraz opowiadań i bajek dla dzieci. Podczas planowania niezwykle ważne było także uwzględnienie powtórzenia poprzednio wyemitowanego materiału i dbałość o stopniowanie trudności zadań przewidzianych w kolejnych audycjach. Ponieważ audycje literackie i umuzykalniające dla przedszkoli miały stanowić całość i wzajemnie się uzupełniać, zaplanowane treści koordynowane były także z działem audycji literackich (Peret-Ziemlańska, 1991: 60).

Po zebraniu tekstów Redakcja Audycji dla Dzieci oceniała przedstawiony materiał. W przypadku braku piosenek czy ilustracji muzycznych zadaniem redaktora muzycznego było złożenie zamówienia u kompozytora lub dobranie materiału muzycznego z fonoteki Polskiego Radia (Hermelin, Korn, Radziwiłł, Wieman, 1956: 87). Warto zauważyć, że większość piosenek wykorzystanych $\mathrm{w}$ audycjach umuzykalniających powstała właśnie w ten sposób. Nie byłoby $\mathrm{w}$ tym nic dziwnego, gdyby nie fakt, że powstały w tym czasie materiał można liczyć w tysiącach utworów, które na stałe weszły do kanonu piosenki przedszkolnej i szkolnej. Przywołajmy słowa Lecha Miklaszewskiego z roku 1963: „Od roku 1947 do chwili obecnej na zamówienie redakcji muzycznej i literackiej programów dziecięcych powstało ponad 1500 pieśni i piosenek do śpiewania przez dzieci od lat 7 do 14" (Kubin, 1964: 62). W liczbie tej nie mieszczą się pieśni i piosenki napisane na zamówienie „Teatru dla Dzieci”, gdyż ich treść związana była bezpośrednio z całością słuchowiska. Nie wiemy, czy w tej liczbie ujęto piosenki dla przedszkoli, prawdopodobnie nie, bowiem wskazane miejsca publikacji piosenek dla dzieci w wieku szkolnym, „Świerszczyk” czy „Płomyczek”, oraz wydania „Piosenek Radiowych dla Dzieci” nie zawierały utworów wykorzystanych w audycjach umuzykalniających. Nie ulega jednak wątpliwości, jak doniosła była rola Polskiego Radia jako mecenasa polskiej piosenki, a przy tym mecenasa młodych kompozytorów, którzy mieli szansę zadebiutować na falach eteru. Przypominając nazwiska osób, które komponowały i pisały teksty piosenek dla przedszkolnych audycji umuzykalniających, należy wymienić: Władysławę Grodzieńską, Barbarę Kossuthównę, Janinę Porazińską, Marię Kaczurbinę, Ewę Szelburg-Zarębinę, Czesława Aniołkiewicza, Feliksa Rybickiego, Jerzego Wasowskiego, Władysława Szpilmana, i wskazaną wcześniej Franciszkę Leszczyńską (Hermelin, 1970: 12).

Literatura stworzona na potrzeby audycji częściowo była publikowana $\mathrm{w}$ książkach metodycznych $\mathrm{z}$ obszaru umuzykalnienia dziecka $\mathrm{w}$ wieku przed- 
szkolnym, jak również w śpiewnikach wydanych przez Polskie Radio. Włączenie dorobku radiowego do dziecięcej literatury muzycznej świadczy o niezwykle wysokim poziomie artystycznym powstałych w tym czasie utworów. Redakcja Audycji dla Przedszkoli, chcąc tworzyć swoje programy w oparciu o najwartościowszy materiał tekstowy i muzyczny, nie ustawała w wysiłkach na rzecz pozyskiwania najzdolniejszych twórców i kompozytorów. W literaturze podkreślany jest fakt, że za granicą rozgłośnie radiowe korzystały z istniejącej oferty wydawniczej, w Polsce natomiast to misja radia wpłynęła na odrodzenie twórczości dla dzieci (Kubin, 1964: 62). Ogłaszane konkursy na słuchowiska dla dzieci, a także prestiż związany z twórczością radiową sprawiły, że wielu młodych twórców podejmowało współpracę z Polskim Radiem, prowadzącą do niezwykle udanych debiutów twórczych. Powstała wówczas na potrzeby audycji literatura wydaje się być niedoścignionym muzycznie i literacko wzorcem kompozycji dla dzieci. Były to niewątpliwie złote czasy piosenki radiowej dla dzieci i młodzieży. Już nigdy twórczość dla dzieci nie osiągnęła takiego rozkwitu.

Piosenki powstałe na zamówienie audycji umuzykalniających ukazały się drukiem $\mathrm{w}$ trzech śpiewnikach. Pierwszy, pod tytułem Lubimy śpiewać, został wydany w 1952 roku przez wydawnictwo Nasza Księgarnia, w roku 1963 nakładem wydawnictwa Czytelnik ukazał się śpiewnik Już śpiewam, ostatni pochodzi z roku 1968, są to Radiowe piosenki przedszkolaków wydane przez Polskie Wydawnictwa Muzyczne. Wiele piosenek trafiło do podręczników autorstwa Marii Wieman, jak choćby $A$ czy wy tak potraficie (1988), Tańce i zabawy ze śpiewem (1961). Autorka przyczyniła się także do stworzenia „Płytoteki dla Przedszkoli” wydanej przez Polskie Nagrania ${ }^{6}$. Płytoteka zawierała nie tylko piosenki pochodzące $\mathrm{z}$ audycji umuzykalniających, ale także przykłady tańców ludowych, ilustracje muzyczne, marsze i akompaniamenty do ćwiczeń. Wszystkie opatrzone były komentarzem metodycznym i przykładowymi ćwiczeniami opisanymi przez Marię Wieman.

Wszystkie podejmowane przez Redakcję Audycji dla Dzieci działania służyły upowszechnieniu materiału audycji muzycznych, by mogły stać się pomocne w codziennej pracy przedszkola.

Polskie Radio jako pierwsze na świecie podjęło inicjatywę zdalnej edukacji muzycznej dzieci w wieku przedszkolnym, nie mogło więc korzystać z wypraco-

\footnotetext{
${ }^{6}$ Pod koniec lat 50. na zlecenie Ministerstwa Oświaty wydawnictwo Polskie Nagrania wraz z Marią Wieman podjęły pionierską inicjatywę wydania pierwszej „Płytoteki Dziecięcej”, inaugurując tym samym działalność fonograficzną przeznaczoną głównie do użytku przedszkolnego. Pierwsza „Płytoteka”, na którą składało się sześć płyt długogrających, została wydana w 1956 roku. Zebrane na płycie utwory zyskały opracowanie muzyczne takich kompozytorów jak Władysław Szpilman, Zbigniew Turski czy Feliks Nowowiejski, warto nadmienić, że współpracy podjął się także Witold Lutosławski. Zob. Mrowiec, 1957, nr 6.
} 
wanych już wzorców, odwoływać się do doświadczeń innych radiofonii ${ }^{7}$ Dlatego uznano wówczas za konieczne nie tylko przeprowadzenie badań i obserwacji przedszkolaków w czasie pierwszych lat emisji audycji, ale przede wszystkim utrzymywanie ścisłego kontaktu $\mathrm{z}$ wychowawczyniami. Podczas badań pilotażowych, przeprowadzonych przez zespół psychologów i pedagogów ${ }^{8}$ w latach 1948-1950, odnotowano, że czas emisji audycji nie może przekroczyć dwudziestu minut, a także, że słuchaczami mogą być głównie dzieci z najstarszej grupy przedszkolnej, bowiem są w stanie skupić swoją uwagę na komunikacie radiowym. Potwierdzono, że kluczową rolę w odbiorze audycji pełni wychowawczyni, będąca pośrednikiem między radiem a dziećmi. Jej przygotowanie do słuchania i współprowadzenia audycji okazało się niezbędne dla pełnego odbioru przekazu radiowego. $\mathrm{Z}$ tą myślą zaczęto emitować specjalne audycje dla wychowawczyń przedszkoli. Przeznaczone dla nich pogadanki miały charakter metodyczny, instruowały, w jaki sposób należy włączać audycje do procesu kształcenia. W prezentowanych w czasie audycji przykładach odnoszono się bezpośrednio do doświadczeń wychowawczyń i odpowiadano na pytania kierowane w listach do redakcji. Audycje te Polskie Radio emitowało od roku 1950 do 1956, następnie zostały częściowo zebrane i opublikowane w roku 1956 w dwóch zbiorach autorstwa Marii Radziwiłł: $W$ naszym przedszkolu oraz $Z$ naszych doświadczeń.

\section{Zabawy przy głośniku}

W programie Polskiego Radia nadawane były trzy rodzaje audycji dla dzieci najmłodszych, czyli w wieku 5-7 lat:

- audycje dla przedszkoli nadawane w ciągu roku szkolnego w każdy wtorek i piątek,

- audycje dla wiejskich dziecińców, emitowane w czasie wakacji letnich,

- audycje dla indywidualnego słuchacza nadawane $\mathrm{w}$ niedzielę i święta (Hermelin, 1970: 20).

Jak wcześniej wspomniano, Polskie Radio początkowo emitowało dla przedszkoli dwa rodzaje audycji: umuzykalniające i literackie, dopiero w roku 1956 wprowadzono audycje ortofoniczne, które nadawano raz w miesiącu (Komunikat..., 1956). Audycje umuzykalniające emitowane były w każdy piątek od

\footnotetext{
${ }^{7}$ Zarówno doświadczenia polskie, jak i zachodnie obejmowały jedynie zdalną edukację muzyczną dzieci w wieku szkolnym. Por. Hermelin, 1970: 7.

${ }^{8} \mathrm{~W}$ pracach zespołu uczestniczyły między innymi Maria Parnowska-Kwiatkowska oraz Halina Korn. Zob. Parnowska, 1956.
} 
godz. 9.40 do godz. 10.00, od 1 września do 30 czerwca (Peret-Ziemlańska, 1990: 59-60). Od początku emitowane były one na falach I Programu Polskiego Radia, w roku 1950 zostały przeniesione na antenę nowo powstałego pasma II Programu.

Audycje umuzykalniające ujęte były w cykle, które na przestrzeni lat ulegały pewnym modyfikacjom. W pierwszym okresie, od roku szkolnego 1948/1949 do roku 1953/1954, wszystkie audycje umuzykalniające nosiły nazwę „Zabawy Rytmiczne". W roku 1957/1958, w związku z wprowadzeniem nowego Programu Tymczasowego Zajęcia $w$ przedszkolu cykle te zostały rozszerzone i aż do roku 1974 ich katalog prezentował się następująco:

- „Zabawy Rytmiczne”,

- „Zabawy z Piosenką”,

- „Z Wierszem i Piosenką",

- „Bawią Się z Nami Goście z Bajki”,

- „Nasze Przedszkolne Tańce”.

Od września 1974 struktura cykli uległa przekształceniom i audycje umuzykalniające emitowano w następującym podziale:

- „Zabawy Przy Muzyce” (zastąpiły wcześniejszy podział na „Zabawy Rytmiczne”, „Zabawy z Piosenką" oraz „Z Wierszem i Piosenką"),

- „Nasze Przedszkolne Tańce”,

- „Nasz Przedszkolny Koncert”,

- „Bawią Się z Nami Goście z Bajki”.

W jednym roku szkolnym emitowano około 45 audycji, z czego większość stanowiły zabawy rytmiczne i zabawy z piosenką, co dowodzi, że za najważniejsze rodzaje aktywności uznawany był śpiew i ruch z muzykąa

Audycje umuzykalniające planowane były zgodnie z obowiązującymi wówczas podstawami programowymi oraz $\mathrm{w}$ oparciu o metodykę umuzykalnienia dzieci najstarszych, czyli sześcioletnich. Mimo iż w badaniach określono, że grupą odbiorców mogą być dzieci w wieku od 5 do 7 lat, audycje nie realizowały treści wychowania muzycznego dla trzech grup wiekowych (5, 6 i 7 lat), natomiast zakładały, że w grupie dzieci sześcioletnich mogły w niektórych placówkach znajdować się wyjątkowo dzieci w wieku 5 i 7 lat.

Odwołując się do współczesnej wiedzy z zakresu edukacji muzycznej, warto przyjrzeć się kolejnym cyklom i omówić realizowane w nich treści i formy umuzykalnienia.

\footnotetext{
${ }^{9}$ Przykładowo w roku szkolnym 1965/1966 w następujący sposób kształtowały się proporcje między cyklami: „Zabawy Rytmiczne” - 20 audycji, „Zabawy z Piosenką” - 10, „Z Wierszem i Piosenką” - 3, „Przedszkolne Tańce” - 4, „Przedszkolny Koncert” - 3, „Bawią się z Nami Goście z Bajki” - 3. Dane zebrane na podstawie badań własnych.
} 


\section{„Zabawy Rytmiczne"}

Był to cykl zabaw najczęściej emitowanych ze względu na duże znaczenie dla rozwoju dziecka. Podstawę ćwiczeń rytmicznych stanowią ćwiczenia koordynacji słuchowo-ruchowej, szybkiej reakcji, rozwijające pamięć muzyczną, motorykę. Dla metody rytmiki charakterystyczne są między innymi ćwiczenia (Brzozowska-Kuczkiewicz, 1991: 32):

- inhibicyjno-incytacyjne,

- ścisłej i swobodnej realizacji rytmów,

- ruchowe, odzwierciedlające przebiegi dynamiczne, agogiczne i artykulacyjne w muzyce,

- ukazujące przebieg linii melodycznej i frazowanie,

- oparte na improwizacji ruchowej i interpretacji ruchowej utworu muzycznego,

- opowieści ruchowe,

- ćwiczenia usprawniające aparat mięśniowy (kształcące dysocjację, świadomość ciała, równowagę) oraz ćwiczenia oddechowe.

Spośród wymienionych ćwiczeń w cyklu „Zabawy Rytmiczne” najczęściej występowały ćwiczenia inhibicyjno-incytacyjne, swobodnej i ścisłej realizacji rytmów oraz ćwiczenia usprawniające aparat mięśniowy. Ćwiczenia inhibicyjno-incytacyjne to ćwiczenia na zatrzymanie i pobudzenie ruchu. Rozwijają umiejętność koncentracji, szybkiej orientacji, mają na celu wykształcenie szybkiej reakcji psychomotorycznej. Opierają się na wykonywaniu różnych czynności ruchowych, takich jak zmiany kierunku ruchu, zatrzymanie, wyklaskanie podanego wcześniej rytmu (Hermelin, 1970: 22). Ćwiczenia te, mimo zabawowej formy, wymagają od ćwiczących niezwykłej koncentracji i skupienia, a także ciągłej mobilizacji mięśniowej, nie powodują jednak uczucia intelektualnego obciążenia i zazwyczaj sprawiają dzieciom wiele radości. Wykonywano je w audycjach systematycznie, zwiększając za każdym razem stopień ich trudności i złożoności.

Ćwiczenia ścisłej i swobodnej realizacji rytmów wykonywane były podczas każdej audycji poprzez wyklaskiwanie tematów rytmicznych, począwszy od jednotaktowych po wielotaktowe (Hermelin, 1970: 22). Powiązane były zawsze z rytmizowaniem tekstu nawiązującego do treści audycji i ułatwiającego zapamiętanie przebiegu rytmicznego. Warto nadmienić, że tematy rytmiczne odpowiednio dobierano do możliwości dzieci. Początkowo realizowano tylko podstawowe wartości i rytmy, które opierały się na ćwierćnutach i ósemkach. W trakcie roku szkolnego jednak - wraz ze wzrastającym poziomem trudności materiału melodycznego i rytmicznego wykorzystanego w piosenkach - tematy rytmiczne były coraz bardziej złożone, pojawiały się $\mathrm{w}$ nich triole, synkopy i realizowały były 
$\mathrm{w}$ taktach ćwierćnutowych i ósemkowych o różnym metrum ${ }^{10}$. Swobodna realizacja rytmu zazwyczaj opierała się na zabawie z rekwizytem, poszukiwaniu czynności i ruchów odzwierciedlających przebieg rytmiczny, wykorzystywano także zabawy inscenizowane czy swobodną improwizację uwrażliwiające na zmiany rytmiczne, dynamiczne i melodyczne. Te ćwiczenia pozwalały nie tylko na rozwijanie poczucia rytmu, muzykalności, ale niejednokrotnie nawiązywały do umiejętności liczenia, kształcenia poczucia czasu muzycznego, poczucia frazy muzycznej itp.

Ćwiczenia usprawniające aparat mięśniowy realizowane były w zasadzie podczas całego czasu trwania audycji, kształciły zdolności manualne, dysocjację, poczucie równowagi, koordynację ruchową.

Audycje „Zabawy Rytmiczne” realizowane były w formie zabawy. Zazwyczaj materiałem formotwórczym audycji była piosenka, a tematykę zabaw osnutych na jej tekście zawsze odnoszono do tematów bliskich przedszkolakom, gdyż audycje były spójne $\mathrm{z}$ bieżącym programem wychowania w przedszkolu (Peret-Ziemlańska, 1990: 57).

\section{„Zabawy z Piosenką"}

W radiu piosenka towarzyszyła wszystkim audycjom umuzykalniającym, jednak występowała w podziale na piosenki do śpiewania oraz do słuchania. Te ostatnie wyodrębniono ze względu na zbyt wysoki poziom trudności oraz ambitus przekraczający skalę głosu dziecka.

Piosenka wprowadzana była raz w miesiącu. Sposób jej uczenia opierał się oczywiście na metodzie ze słuchu. Wprowadzeniu piosenki towarzyszyły ćwiczenia intonacyjne, melodyczne oraz rytmiczne, pozwalające na utrwalanie trudniejszych lub bardziej złożonych jej fragmentów (Hermelin, 1970: 24). Dostęp do materiału nutowego do większości wykonywanych piosenek miał nauczyciel, ponieważ publikowane były na bieżąco w miesięcznikach „Wychowanie w Przedszkolu” oraz „Radio i Świat”.

Piosenki stanowiły materiał nie tylko do zabaw rytmicznych, ale wykorzystywane były często $\mathrm{w}$ opowieściach ruchowych i zabawach inscenizowanych, w których dzieci przy akompaniamencie piosenki, z podziałem na role, realizowały jej treść. Piosenki stanowiły także tło muzyczne zabaw tanecznych.

Śpiew jako główna forma umuzykalnienia był jedną $\mathrm{z}$ najważniejszych aktywności dzieci. Podkreślano, że powinien stale towarzyszyć dzieciom, nie tylko podczas słuchania audycji, ale też przy codziennej zabawie. W audycjach

\footnotetext{
${ }^{10}$ Na podstawie badań własnych.
} 
pojawiał się śpiew solowy i zbiorowy, z podziałem na role, tak by najmłodsi poznawali różne formy zabaw ze śpiewem.

W audycjach szczególną uwagę zwracano na prawidłową intonację, postawę dzieci podczas śpiewu oraz jego estetykę (Hermelin, 1970: 24). Audycjom towarzyszyły zawsze uwagi wykonawcze i przypomnienia o przyjęciu właściwej pozycji w czasie śpiewu. Nauka piosenki kilkuzwrotkowej rozłożona była na kilka tygodni. Zgodnie ze wskazaniami metodycznymi podczas pierwszej audycji prezentowana była $\mathrm{w}$ całości, jej treść omawiana, a następnie wykonana była ponownie (Hermelin, 1970: 24-25). Czasem w zabawach rytmicznych utrwalane były fragmenty refrenu, a treść piosenki wykorzystywano jako inspirację ćwiczeń ruchowych (Hermelin, 1970). Podczas kolejnych audycji następowała nauka kolejnych zwrotek - jednej w trakcie audycji. Nigdy nie skracano treści piosenek, nawet gdy były długie, czterozwrotkowe, gdyż sprzyjało to ćwiczeniu pamięci dzieci.

W czasie roku szkolnego dzieci poznawały od 6 do 8 piosenek (Hermelin, 1970: 25). Były one przypominane, utrwalane, opracowywane w różnorodny sposób. Repertuar czerpano głównie z polskiego folkloru, istniejących śpiewników lub zamawiano u kompozytorów specjalnie na potrzeby audycji (Hermelin, 1970: 24).

\section{„Z Wierszem i Piosenkq"}

Ten cykl miał zwrócić uwagę dzieci na treść piosenki lub wiersza i zachęcić do twórczego przekazania jej w ruchu, dlatego najczęściej spotykaną formą aktywizacji słuchaczy w trakcie audycji było tworzenie opowieści ruchowej (Hermelin, 1970: 26). Opowieść ruchowa jest jednym z najbardziej lubianych przez dzieci ćwiczeń, uwalnia bowiem wyobraźnię, pozwala na swobodną improwizację i indywidualne odkrywanie muzyki. Ideą ćwiczenia jest stworzenie opowiadania ilustrowanego muzyką i ruchem. Ponieważ inspiracją dla ćwiczeń może być wiersz, fragment prozy, treść piosenki, w audycjach odnajdziemy wszystkie wymienione formy. Ilustracja muzyczna, która podkreśla warstwę literacką, towarzyszy improwizacji dzieci poprzez sugestywne używanie dynamiki, tempa, melodyki i barwy dźwięku, organizuje działania ruchowe najmłodszych. Współcześnie $\mathrm{w}$ edukacji muzycznej opowieść ruchowa często stosowana jest, by uwrażliwić dziecko na poszczególne elementy dzieła muzycznego (kierunek linii melodycznej, zmiany tempa, kontrasty dynamiczne) oraz inspirować do poszukiwania różnych środków wyrazowych, stymulować kreatywność (Ławrowska, 2005: 223-225). Celem tych audycji była integracja słowa i muzyki, pobudzanie wyobraźni dzieci do wspólnego tworzenia niematerialnej rzeczywistości. 
Tematy poruszane $\mathrm{w}$ opisywanych audycjach odnosiły się zawsze do pozytywnych uczuć i emocji.

Innym sposobem wykorzystania treści wiersza i piosenki było tworzenie szeregu ćwiczeń rytmicznych i ruchowych nawiązujących do ich treści. Materiał literacki stanowił punkt wyjścia do ćwiczeń realizacji rytmów, ćwiczeń inhibicyjno-incytacyjnych oraz zabaw ruchowych rozwijających motorykę itp. Najważniejszą cechą tych audycji było oddziaływanie wychowawcze, integrowanie treści audycji z innymi obszarami wiedzy oraz uwrażliwianie na piękno mowy ojczystej i nauka poprawnej polszczyzny.

\section{„Bawią Się z Nami Goście z Bajki”}

Elementem formotwórczym tego cyklu była bajka lub opowiadanie, które dzieci poznawały, słuchając wtorkowej audycji literackiej, poprzedzającej zabawy umuzykalniające. Podczas piątkowej audycji następowało krótkie przypomnienie bajki, po czym rozpoczynała się opowieść, w której dzieci zamieniały się w postaci opowiadania ${ }^{11}$. Przygotowane wcześniej przez wychowawczynię rekwizyty wpływały na „teatralność" zabawy (Hermelin, 1970: 26). Prowadzone w oparciu o ilustrację muzyczną ćwiczenia niosły zawsze wartości dydaktyczne. Przykłady realizowanych ćwiczeń to: rytmizacja prostych tekstów, reagowanie na umówiony sygnał muzyczny, śpiewanie krótkich motywów melodycznych, ćwiczenia porządkowe, uwrażliwiające na elementy dzieła muzycznego i wiele innych ${ }^{12}$. Podjęte ćwiczenia i zabawy sprzyjały utrwaleniu i zapamiętaniu treści wychowawczych opowiadania. Ten cykl cechowała wyjątkowa poetyckość, troska o piękno słowa, ale także akcentowanie treści i momentów wychowawczych, które niósł wykorzystany w audycji utwór literacki.

\section{„Nasze Przedszkolne Tańce”}

Na ten cykl w ciągu roku składała się nauka około 3-4 tańców regionalnych, dziecięcych tańców innych narodów oraz zabaw tanecznych (Hermelin, 1970: 26). Polskie tańce regionalne opracowywała Maria Wieman tak, by mimo uproszczenia kroków tanecznych charakter tańca pozostał niezmieniony. Poza kształceniem koordynacji ruchowej i umiejętności tanecznych celem audycji było przede wszystkim zapoznanie dzieci z rodzimym folklorem, stąd wiele uwagi poświęcano omówieniu regionu, z którego taniec pochodzi, strojów ludowych, charakteru

\footnotetext{
${ }^{11}$ Na podstawie badań własnych.

${ }^{12} \mathrm{Na}$ podstawie badań własnych.
} 
tańca, jego budowie, dynamice i tempu ${ }^{13}$. Nauka odbywała się w czasie audycji „Nasze Przedszkolne Tańce”, natomiast prezentowany taniec powtarzany był w czasie kolejnych audycji wielokrotnie ${ }^{14}$. Trudnością realizacyjną tego cyklu był brak możliwości bezpośredniego zaprezentowania kroków oraz bieżącego dostosowania tempa akompaniamentu do tempa poruszania się dzieci.

Już podczas planowania audycji dokładano szczególnych starań, by sposób wprowadzenia tanecznych kroków realizowany był zgodnie z zasadą stopniowania trudności. Każdy taniec poprzedzało nie tylko uważne wysłuchanie muzyki i jej analiza, ale także ruchowe ćwiczenia przygotowawcze obejmujące poszczególne elementy tańca ${ }^{15}$. Dopiero na końcu łączono je w całość i wykonywano w odpowiednim tempie. Zadaniem audycji było przybliżanie najmłodszym rodzimego folkloru, na co szczególny nacisk kładły wówczas obowiązujące programy wychowania w przedszkolu.

Wielką pomocą była w trakcie audycji obecność wychowawczyni, która wspomagała proces nauki, mogła prezentować prawidłowe wykonanie figur tanecznych i utrwalać po zakończeniu audycji nowo poznaną choreografię.

\section{„Przedszkolny Koncert”}

Audycje te redagowane były z myślą o edukacji przyszłych odbiorców muzyki. Miały na celu wykształcenie kultury słuchania muzyki, przyswajanie zasad zachowania obowiązujących na koncercie, w teatrze czy operze (Hermelin, Korn, Radziwiłł, Wieman, 1956: 30). Poza celami wychowawczymi audycje realizowały zadania czysto muzyczne, takie jak umiejętność podstawowej analizy utworu muzycznego, kształcenie pamięci muzycznej czy gra na instrumentach perkusyjnych.

Każdemu z tych celów przyporządkowany był inny rodzaj audycji. Audycje poświęcone słuchaniu muzyki zaznajamiały z brzmieniem instrumentów, uczyły rozróżniania głosów w śpiewie, określania budowy utworów muzycznych, ich charakteru, tempa, melodyki itp. (Hermelin, Korn, Radziwiłł, Wieman, 1956: 30). Z kolei audycje o podtytule "Czy pamiętasz" w ramach koncertu przypominały dzieciom poznane dotychczas melodie piosenek i tańców. Ich celem było kształcenie pamięci muzycznej, rozpoznawanie znanego utworu na podstawie usłyszanego fragmentu melodii czy charakterystycznego rytmu (Hermelin, 1970: 28). „A w naszej orkiestrze” to audycje w których dzieci kształciły umiejętności wy-

\footnotetext{
${ }^{13} \mathrm{Na}$ podstawie badań własnych.

${ }^{14} \mathrm{Na}$ podstawie analizy konspektów audycji.

${ }^{15} \mathrm{Na}$ podstawie analizy konspektów audycji.
} 
konawcze w ramach przedszkolnej orkiestry perkusyjnej (Hermelin, 1970: 28). Jej repertuar stanowily zazwyczaj znane dzieciom piosenki i tańce ludowe.

Zastosowany przez Marię Wieman podział na cykle wpływał na różnorodność kontaktów dzieci z muzyką, zachęcał do podejmowania wszystkich form muzycznej aktywności. Autorka starała się integrować treści audycji umuzykalniających z innymi obszarami wiedzy, szczególnie literackiej, matematycznej, ale także przyrodniczej. W sposób wyjątkowy audycje prezentowały polski folklor, czyniąc z nauki tańca także pretekst do charakterystyki poszczególnych regionów, strojów ludowych i gwary. Integracja treści nauczania wydawała się autorce czymś oczywistym i naturalnym, bowiem wszystkie działania podejmowane w edukacji i wychowaniu dziecka w wieku przedszkolnym mają służyć wzbogacaniu jego wiedzy i rozwojowi osobowości.

\section{Do widzenia Pani. Do widzenia dzieci}

Sukces edukacyjny radiowych audycji umuzykalniających zyskał międzynarodowy wymiar w roku 1966, kiedy audycja Marii Wieman W majowym słońcu zdobyła nagrodę Prix Japan za najlepszą audycję dla dzieci na świecie. Sama autorka wspomina, że wysłano audycję ,jedną z wielu”, która rzeczywiście nie wyróżniała się spośród pozostałych. Ten spektakularny sukces był dowodem wielkiego profesjonalizmu autorki i zespołu redakcyjnego.

Dla Marii Wieman największą wartość stanowiły jednak listy wychowawczyń przedszkoli oraz bieżący z nimi kontakt. Autorka wizytowała placówki przedszkolne, doradzała, jak w pełni wykorzystać audycje, prowadziła także letnie kursy uzupełniające wiedzę muzyczną wychowawczyń. Korespondencja nauczycielek była częściowo publikowana na łamach czasopisma „Wychowanie w Przedszkolu”. Głos z terenu, jak wówczas pisano, był świadectwem niezwykłych emocji, jakie wzbudzały audycje $\mathrm{w}$ placówkach przedszkolnych. Obcowanie $\mathrm{z}$ radiem miało wówczas odświętny charakter, piątkowe audycje były wyczekiwane, a dla wychowawczyń stanowiły źródło wiedzy i niezwykle istotną pomoc dydaktyczną. Warto przytoczyć choćby słowa pochodzące z listu wychowawczyni ze wsi Bolechowice:

(...) Ach, jakże przydałyby się nam częstsze audycje - takie, jak w piątki (umuzykalniające). Nasze dzieci stęsknione są za muzyką, gdyż nie posiadamy instrumentu i w ogóle nasze przedszkole jest słabo wyposażone, jest w trakcie rozwoju. Biedne dzieciaki nie mają pojęcia o takich zabawkach i grach, jakie mają inne przedszkola, toteż audycje są dla nich jedyną atrakcją, rozrywką i utęsknieniem. (Hermelin, Korn, Radziwiłł, Wieman, 1956: 21)

Spośród wyemitowanego przez Polskie Radio materiału zachowało się jedynie 212 fonogramów w Archiwum Polskiego Radia. Powszechny jest jednak 
dostęp do konspektów w archiwalnych numerach czasopisma „Wychowanie w Przedszkolu”. Lektura konspektów pochodzących choćby z jednego rocznika niezwykle wzbogaci wiedzę nauczycieli wychowania przedszkolnego czy osób prowadzących zajęcia rytmiki w przedszkolu. Wnikliwy czytelnik z pewnością dostrzeże nie tylko poprawność metodyczną tamtych audycji, ale ujmie go także ich przejrzystość, dziecięca prostota i wysoki poziom muzykalności.

\section{Literatura}

Brzozowska-Kuczkiewicz M. (1991). Emil Jaques-Dalcroze i jego rytmika. Warszawa.

Gawrecki L. (1990). Radio w nauczaniu i wychowaniu. Kalisz.

Hermelin H. (red.). (1950). Radio w przedszkolu. Warszawa.

Hermelin H. (red.). (1970). Radio w przedszkolu. Poradnik dla wychowawczyń przedszkoli. Warszawa.

Hermelin H., Korn H., Radziwiłł M., Wieman M. (1956). Radio w przedszkolu. Warszawa.

Kaziów M. (1973). O dziele radiowym. Z zagadnień estetyki oryginalnego słuchowiska. Wrocław.

Kubin J. (1957). Audycje radiowe w szkole. Warszawa.

Kubin J. (1964). Radio i wychowanie. Warszawa.

Ławrowska R. (1988). Muzyka i ruch. Warszawa.

Ławrowska R. (2005). Rytm, muzyka, taniec w edukacji. Podręcznik dla studentów i nauczycieli pedagogiki przedszkolnej i wczesnoszkolnej. Kraków.

Parnowska M. (1956). Audycje dla przedszkoli w świetle wstępnych badań. [W:] H. Hermelin, H. Korn, M. Radziwiłł, M. Wieman (red.). Radio w przedszkolu. Poradnik dla wychowawczyń przedszkoli. Warszawa.

Peret-Ziemlańska Z. (1990). Rozmowy z Mariq Wieman. Warszawa.

Przychodzińska-Kaciczak M. (1979). Polskie koncepcje powszechnego wychowania muzycznego. Tradycje - współczesność. Warszawa.

Radziwiłł M. (1956) W naszym przedszkolu. Pogadanki radiowe dla wychowawczyń przedszkoli. Warszawa.

Radziwiłł M. (1957). Z naszych doświadczeń. Pogadanki radiowe dla wychowawczyń przedszkoli. Warszawa.

Radziwiłł-Wąsowiczowa M. (1956). W naszym przedszkolu. Pogadanki radiowe dla wychowawczyń przedszkoli. Warszawa.

Radziwiłł-Wąsowiczowa M. (1957). Z naszych doświadczeń. Pogadanki radiowe dla wychowawczyń przedszkoli. Warszawa.

Wieman M. (1950). Zabawy ze śpiewem. Warszawa.

Wieman M. (1959). Dziesięciolecie przedszkolnych audycji umuzykalniających. „Wychowanie w Przedszkolu” nr 12.

Wieman M. (1961). Tańce i zabawy ze śpiewem dla dzieci od 7 do 14 lat. Warszawa.

Wieman M. (1988). A czy Wy tak potraficie? Piosenki, zabawy i tańce dla dzieci w wieku 3-7 lat. Warszawa. 
Materiały źródłowe

Instrukcja $z$ dnia 29 maja 1948(Nr II WP-2732/48) w sprawie organizacji wychowania przedszkolnego na rok 1948/49, Dziennik Urzędowy Ministerstwa Oświaty 1948 Nr 6, Poz. 111, s. 225-226.

Ministerstwo Oświaty, Projekt Programu wychowania w Przedszkolu, Państwowe Zakłady Wydawnictw Szkolnych, Warszawa 1949.

Ministerstwo Oświaty, Program Tymczasowy „Zajęcia w przedszkolu”, Państwowe Zakłady Wydawnictw Szkolnych, Warszawa 1950.

Okólnik Nr 28, z dnia 6 listopada 1948, w sprawie radiofonizacji szkół, Dziennik Urzędowy Ministerstwa Oświaty Nr 12, Poz. 227, s. 539. 